\title{
Collateral on Strategic Access to Credit Facilities by Women Owned Small and Medium Enterprises (SMEs)
}

\author{
Charles Mwirigi \\ Jomo Kenyatta University of Agriculture and Technology (JKUAT) \\ Nairobi Kenya \\ Prof. Roselyn Wangari Gakure \\ Jomo Kenyatta University of Agriculture and Technology (JKUAT) \\ Nairobi Kenya \\ Prof. Romanus Odhiambo Otieno \\ Jomo Kenyatta University of Agriculture and Technology (JKUAT) \\ Nairobi Kenya
}

\begin{abstract}
The purpose of this study is to establish the characteristics of owners of Business on strategic access to credit facilities by Women owned small and medium enterprises (SMEs). The study adopted a descriptive research design guided by cross sectional survey. The target population was drawn from women owned enterprises specifically owners of businesses in Nairobi, Kenya. A sample of $\mathbf{3 7 0}$ was derived from the population. A pilot will be conducted to ascertain the validity and reliability of the instrument. Data collected from the respondents was captured in SPSS version 24 and analyzed using both descriptive and inferential statistics (correlation analysis and multiple regressions) to establish hypothesized relationships between the variables. The results were presented in form of tables, graphs, charts, means, standard deviations, $t$ and $f$ statistics. The findings of the study revealed that characteristics of business owners, collateral, networking and interest rates statistically and significantly predicts the Strategic access to credit SMEs owned by women (i.e., the regression model is a good fit of the data) and that interest rates significantly influence the Strategic access to credit SMEs owned by women in Kenya.
\end{abstract}

Key Words: Collateral, Strategic Access to Credit

\section{INTRODUCTION}

Collateral refers to something pledged as security for repayment of a loan, to be forfeited in the event of a default. It's a fallback or indemnity (6). The small and medium enterprises (SMEs) owned by women are acknowledged as the engines through which the growth objectives of the developing countries can be achieved. Despite their potential to create employment, create wealth and develop innovation in many developing countries, women owned SMEs encounter various problems and as a result many perform dismally and fail to grow (1). Such problems include inability to access credit from financial institutions. The provision of credit has increasingly been regarded as an important tool for raising incomes of populations, mainly by mobilizing resources to more productive uses (4). A study by (8) asserts that in Kenya is hindered by numerous factors such as low levels of education, high interest rates, low business incomes and many other socio-cultural aspects that put women in lower status in the society compared to men as far as operation of the businesses is concerned. 


\section{STATEMENT OF THE PROBLEM}

There are various constraints that hamper the smooth access to credit from the formal financial institutions by SMEs owned by women. These constraints include lack of information, unfriendly collateral requirements, high interest rates and poor strategic planning (6). Though the government has been making efforts to help SMEs develop through various programs and policies such as affirmative action Funds (for women and youth empowerment) and provision of the necessary infrastructure as outlined in several policy documents since independence (8), no success has been registered pertaining growth of women owned SMEs. Therefore, there is long way to go for SMEs owned by women in Kenya to attain full potential and efficiencies due to lack of access to credit. Access to credit is connected to improved performance of SMEs in Kenya ((15). The incapability to access credit by the SMEs is a major limitation on the business growth and development in Kenya (12). Eighty-five percent (85\%) of Kenyan SMEs are credit constrained and cannot afford the security demanded by the banks that may be valued up to $200 \%$ of the loan (13). This study therefore sought to determine whether collateral affects strategic access to credit facilities by women owned small and medium enterprises in Kenya.

\section{RESEARCH QUESTION}

The study sought to answer a key question:

Is there any significant relationship between collateral and strategic access to credit facilities by women owned small and medium enterprises in Kenya?

\section{LITERATURE REVIEW}

The study focused on constraints theory. The basic premises of the theory of constraints assume that people can think they are good and systems are simple yet, there must be something missing. The theory argues that an organization facing challenges in cost management, poor performance and chronic conflicts is as a result of poor management practices and lack of necessary intervention (9). In his study, he developed the theory of constraints to help organizations decide what to change, identify a desirable new condition and how to trigger the change. He recommended first identifying the main factors affecting budget estimates in an organization and then suggested that manager's figure out how to handle the constraints or barrier to success within prescribed budget.

By focusing on fixing the main problem, overall performance could be improved (10). Additionally, (11) observed that most organizations fail to examine their operations as a whole when developing cost estimates (5). By focusing only on short-term goals, long-term success becomes jeopardized so he suggested establishing a long-term view. According to this theory, all systems operate in an environment of cause and effect. One event causes another to happen thus prompting for factors analysis as a measure. Capturing the essence of cause and effect within the system and identifying factors that emulate these relationships are key to system performance and excellent adherence to cost estimates (13). The theory approach is on successful on-time completion of a project.

Literature revealed that constraints theory is related to this study in that many business owned by women are unable to comply with the high costs of funds, difficulties in assessing and managing their risk profile as well as lack of the required collateral security (16). This makes it complicated for financial institutions to grant the credit facilities as they are considered risky customers. The financial institutions therefore put conditions to the business which they can't comply with leading to failure to access credit. 


\section{CONCEPTUAL FRAMEWORK}

Literature Review revealed that Women in Middle East and North African countries discovered that women have less inheritance rights than men when it comes to touchable material goods that can be used as security to access credit from financial institutes. The report further point out that women only own 1 percent of the world's possessions and in two thirds of countries and that the legal constitutional rights of women decline with marriage. In Kenya although inheritance laws were raised with the succession Act of 1981, still a greater percentage of women have properties in their own rights and rarely inherited land.

Customary rules and legal regulations are often restricting women's control and access to over tangible assets access that can be accepted as collateral such as land or livestock. Females are not likely to have land titles under their names, despite their families owning land, and they are not likely to have control over land than men even when they formally own it. Subjective inheritance rights have often granted land to male relatives, leaving both and daughters and widows at a disadvantage (2). (7) observed that rural women entrepreneurs are more credit constrained than men of equivalent socio-economic conditions. This is because men have traditional rights to own land and thus they have collaterals that give them ability to borrow.

Credit conditions when forming a group, paying membership fees, group registration fees and joining saving plans, result in delays in accessing initial capital, thereby worsening the women's household financial burden (3). However, this is no longer the key barrier and constraint, but lack of creativity, innovativeness and responsiveness (by capital suppliers) now hampers women's entrepreneurship in Kenya. While many MFIs emerged to present initial relevance and working capital, cost-effectiveness is frequently inappropriate in gratifying the particular needs of operating and potential women entrepreneurs.

Arising from the literature review, the following represents the conceptual framework of the study.

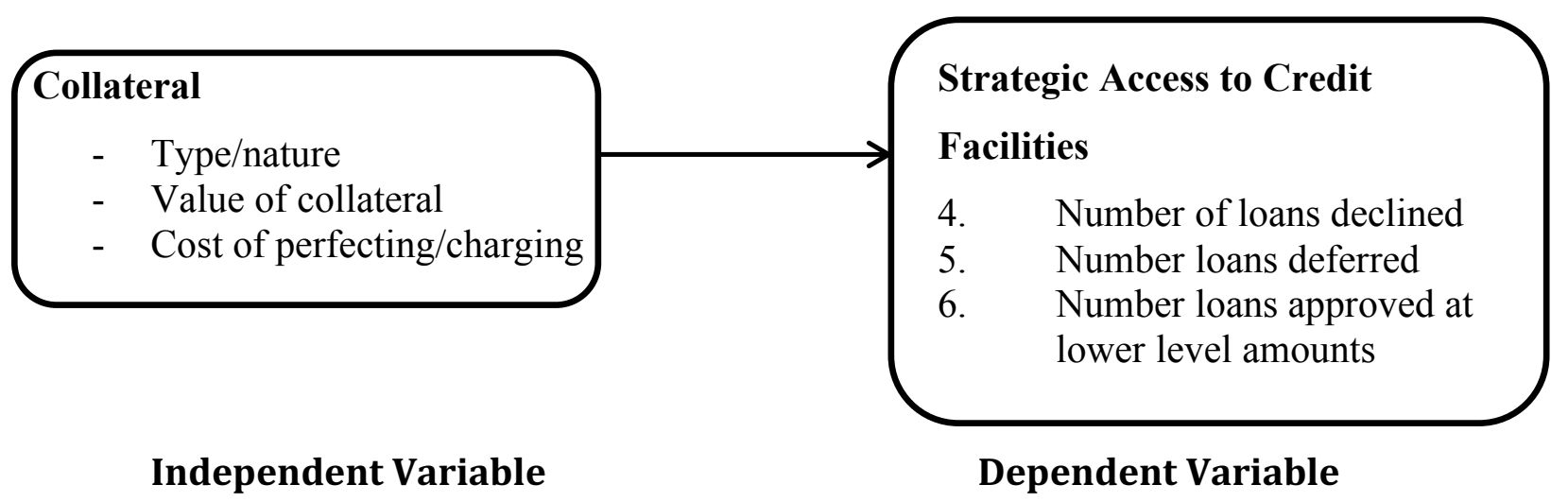

Figure 1: Conceptual Framework

\section{RESEARCH METHODOLOGY}

To determine whether collateral affects strategic access to credit facilities by women owned small and medium enterprises in Kenya, this study adopted descriptive research design guided by cross sectional survey in order to provide a framework to examine current conditions, trends and status of events. Data was collected over a period of over one and a half months from a sample of 380 SMEs in Nairobi County. The correlation analysis was used to analyze the positive correlation between the dependent and independent variables. The strength of the relationship was tested by R-squared which also tested the model to determine its goodness fit. 


\section{MEASUREMENT OF VARIABLES}

The variables of this study were measured using continuous indicators. Collateral was measured by three items namely: type and nature, value of collateral and Cost of charging property held as security. Type and nature of collateral security influences the decision of financial institutions to give credit to women owned businesses. Financial institutions insist on the provision of collateral by businesses owned by women as a primary lending condition. A five point Likert scale ranging from one (Strongly disagree) to five (Strongly agree) was used. The findings support the work done by (4) on the access to credit by small and medium enterprises owned by women which revealed that commercial banks and other formal financial institutions fail to cater for the credit needs of women who are smallholder business entrepreneurs, mainly due to the fact that the women entrepreneurs do not have tangible assets to meet the lending terms and conditions relating to collateral requirements. (4) concluded that it is generally the rules and regulations of the commercial banks and other formal financial institutions that have created the myth that the small medium and micro enterprises are not credit worth since they cannot afford the required collateral. The findings concurs with those of a study conducted in Ghana by (17) to examine the challenges faced by Small \& Medium Enterprises (SMEs) in accessing credit with revealed that the inability of SMEs to own highly valued assets to provide as collateral to financial institutions make it extremely difficult to access credit.

\section{Descriptive Analysis for Collateral}

RESEARCH FINDINGS AND DISCUSSION

The study sought to establish the extent of influence of collateral on the Strategic access to credit by women owned SMEs. The following 3 sub-variables were measured; i) Type and nature ii) Value of collateral and iii) Cost of charging property held as security. In regards to the nature of collateral security influences the decision of financial institutions to give credit to women owned businesses. The results are as follow: 9\% strongly disagreed with the statement, $21 \%$ disagreed, $26 \%$ were neutral, $28 \%$ agreed with the statement while $16 \%$ of the respondents strongly agreed. From the foregoing, majority of the respondents (44\%) agreed with the statement. This implies that the nature of collateral security provided influences the decision of financial institutions to give credit to women owned businesses. The higher the liquidity or marketability of collateral, the higher the chances that financial institutions will issue credit. This is the basis financial institutions insist on the provision of collateral by businesses owned by women as a primary lending condition. Lack of appropriate types of collateral therefore hinders Strategic Access to Credit by women owned SMEs.

To measure if value of collateral security influences the decision of financial institutions to give credit to women owned businesses. The findings are as follow: 7\% strongly disagreed with the statement, $18 \%$ disagreed, $30 \%$ were neutral, 35\% agreed with the statement while $10 \%$ of the respondents strongly agreed. From the foregoing, majority of the respondents (45\%) agreed with the statement. This implies that value of collateral security provided influences the decision of financial institutions to give credit to women owned businesses. Financial institutions have lending margins depending on the marketability and type of security. The higher the value, the higher the chances that the lender will grant loan against the security.

To measure the cost of perfecting collateral security i.e. legal process of charging and assigning collateral security to the financial institution affects access to credit facilities. The results are as follows: $16 \%$ strongly disagreed with the statement, $18 \%$ disagreed, $22 \%$ were neutral, $38 \%$ agreed with the statement while $6 \%$ of the respondents strongly agreed as illustrated in Table 4.12. From the foregoing, majority of the respondents (44\%) agreed that cost of perfecting collateral security affects credit access by women owned SMEs. 
Table 1: Collateral

\begin{tabular}{lccccccc}
\hline Collateral & 1 & 2 & 3 & 4 & 5 & $\mu$ & SD \\
\hline $\begin{array}{l}\text { The nature of collateral security has } \\
\text { influenced the decision of financial } \\
\text { institutions to give credit to women } \\
\text { owned businesses }\end{array}$ & $9 \%$ & $21 \%$ & $26 \%$ & $28 \%$ & $16 \%$ & 2.7 & .825 \\
$\begin{array}{l}\text { The value of collateral security } \\
\text { influenced the decision of financial }\end{array}$ & $7 \%$ & $18 \%$ & $30 \%$ & $35 \%$ & $10 \%$ & 3.1 & .628 \\
$\begin{array}{l}\text { institutions to give credit to women } \\
\text { owned businesses }\end{array}$ & & & & & & & \\
$\begin{array}{l}\text { The cost of perfecting collateral } \\
\text { discouraged business owners from } \\
\text { applying for credit facilities from } \\
\text { financial institutions }\end{array}$ & $6 \%$ & $18 \%$ & $22 \%$ & $38 \%$ & $6 \%$ & 2.8 & .802 \\
\hline
\end{tabular}

$\mathrm{n}=370, \mathrm{SD}=$ Standard Deviation

1= Strongly Disagree, 2= Disagree, 3= Neutral, 4= Agree and 5= Strongly Agree .

Various factors were used to measure Strategic Access to Credit in the study. The study results outlined that $10 \%$ strongly disagreed with the statement, $23 \%$ disagreed, $19 \%$ were neutral, $30 \%$ agreed with the statement while $18 \%$ of the respondents strongly agreed. From the foregoing,

majority (48\%) of the respondents agreed with the statement. When asked if loan applications from women owned SMEs are deferred due to lack of sufficient information business andfinanc ial records, proper documentation and appropriate collateral. The results are as follow: 9\% strongly disagreed with the statement, 15\% disagreed, $21 \%$ were neutral, $37 \%$ agreed with the statement while $19 \%$ of the respondents strongly agreed. From the foregoing, majority (56\%) respondents agreed with the statement.

The study sought to establish if the ability to repay a loan influences financial institutions to reduce loan amounts to mitigate on risk of default. The results are as follow: $6 \%$ strongly disagreed with the statement, $7 \%$ disagreed, $20 \%$ were neutral, $41 \%$ agreed with the statement while $26 \%$ of the respondents strongly. From the foregoing, majority $(67 \%)$ of the respondents agreed with the statement.

Table 2: Descriptive Analysis of Strategic Access to Credit by Women Owned SMEs

\begin{tabular}{|c|c|c|c|c|c|c|c|}
\hline Strategic Access to Credit & 1 & 2 & 3 & 4 & 5 & $\mu$ & SD \\
\hline $\begin{array}{l}\text { Loan requests from women owned SMEs } \\
\text { are declined due to lack of appropriate } \\
\text { collateral security }\end{array}$ & $10 \%$ & $23 \%$ & $19 \%$ & $30 \%$ & $18 \%$ & 2.85 & .734 \\
\hline $\begin{array}{l}\text { Loan requests from women owned SMEs } \\
\text { are deferred due to lack of sufficient } \\
\text { Information, business \& financial records } \\
\text { and proper documentation }\end{array}$ & $9 \%$ & $15 \%$ & $21 \%$ & $37 \%$ & $19 \%$ & 3.37 & .608 \\
\hline $\begin{array}{l}\text { Loan requests from women owned SMEs } \\
\text { are approved depending on the business's } \\
\text { ability to repay }\end{array}$ & $6 \%$ & $7 \%$ & $20 \%$ & $41 \%$ & $26 \%$ & 4.00 & .250 \\
\hline
\end{tabular}

$\mathrm{n}=370, \mu=$ Mean, $\mathrm{SD}=$ Standard Deviation

1= Strongly Disagree, $2=$ Disagree, $3=$ Neutral, $4=$ Agree and 5= Strongly Agree . 


\section{Correlation Analysis}

Collateral had a positive and significant correlation with Strategic access to credit ( $\mathrm{r}=0.242$, $\mathrm{p}$ value $<0.05)$. This means a unit value of collateral increases the strategic access to credit by 0.242 .

Table 3: Correlations Analysis

\begin{tabular}{llcc}
\hline & & Strategic access to credit & Collateral \\
\hline Strategic Access & Pearson Correlation & 1 & $.242^{* *}$ \\
to credit & Sig.(2-tailed) & & .000 \\
& $\mathrm{~N}$ & 370 & 370 \\
\hline
\end{tabular}

**. Correlation is significant at the 0.05 level (2-tailed).

\section{Regression Analysis}

$\mathbf{H}_{\mathbf{0} 1:}$ There is significant relationship between collateral and strategic access to credit facilities by women owned small and medium enterprises in Kenya.

\section{Collateral and Strategic Access to Credit Facilities Model Summary}

The coefficient of determination (R squared) of 0.193 indicates that $19.3 \%$ of strategic access to credit can be explained by collateral. The adjusted R square of $17.2 \%$ explains that collateral in the exclusion of the constant variable explain there is no change in strategic access to credit. The remaining percentage can be explained by other factors not included in the model. The $\mathrm{R}$ indicates the correlation coefficient of characteristics of owners of business, an $\mathrm{R}=0.440$ shows that there is a positive relationship between characteristics of owners of business and strategic access to credit. The standard error of estimate (2.19) shows the average deviation of the independent variables from the line of goodness fit.

Table 4: Collateral and Access to Credit Model Summary

\begin{tabular}{ccccc}
\hline Model & $\mathbf{R}$ & $\mathbf{R}^{2}$ & Adjusted $\mathbf{R}^{2}$ & Std. Error of the Estimate \\
1 & $.440^{\mathrm{a}}$ & .193 & .172 & .2190 \\
\hline
\end{tabular}

a. Predictors: (Constant), Collateral

\section{Collateral and Access to Credit}

The F statistics was used to test for the model goodness of fit. Table 5 ( $F=61.132$, $p$ value $=0.000$ ) indicates that there is a significant relationship between characteristics of business owners and access to credit and at least the slope ( $ß$ coefficient) is not zero.

Table 5: Collateral and Access to Credit

\begin{tabular}{llccccc}
\hline Model & & Sum of Squares & d.f & Mean Square & F & Sig. \\
\hline \multirow{2}{*}{ Regression } & 229.890 & 1 & 229.890 & 61.132 & .000 \\
& Residual & 800.980 & 369 & 3.7605 & & \\
& Total & 1030.870 & 370 & & & \\
\hline
\end{tabular}

\section{Collateral and Access to Credit Regression Weights}

The study hypothesized that collateral affects the strategic access to credit. The study findings showed that there was a positive and significant relationship between collateral and strategic access to credit $(\beta=0.208$, $p$-value $=0.000<0.05)$. This means that a unit increase in collateral leads to an increase in strategic access to credit by 0.208 . Since the p value was less than 0.05 , the null hypothesis was accepted and the alternative hypothesis was rejected. The study therefore concluded that collateral has a significant influence on strategic access to credit. 
Table 6: Collateral and Access to Credit Regression Weights

\begin{tabular}{cccccc}
\hline & \multicolumn{2}{c}{ Unstandardized } & \multicolumn{2}{c}{$\begin{array}{c}\text { Standardized } \\
\text { Coefficients }\end{array}$} & $\begin{array}{c}\text { Coefficients } \\
\text { Beta }\end{array}$ \\
Model & B & Std. Error & T & Sig. \\
\hline $1 \quad$ (Constant) & 1.905 & .200 & & 9.525 & .000 \\
Collateral & -.389 & .057 & .187 & 6.824 & .000 \\
\hline
\end{tabular}

a. Dependent Variable: Access to Credit

\section{DISCUSSION}

The findings of the study do not contradict the research hypothesis that collateral affect the strategic access to credit. The results of the regression analysis indicate that collateral has significant effect on strategic access to credit. Collateral was second compared to other variables and this is an implication that strategic access to credit is highly influenced by collateral. This is supported by (14) who stated that the level of credit worthiness play a key role in stimulating entrepreneurship orientation which influences the access to credit by small and medium enterprises.

\section{SUMMARY AND CONCLUSION}

The objective of this paper was to investigate the effect of collateral on strategic access to credit in Nairobi Kenya. It was established that financial constraints limits the investment capacity of SMEs and thus hamper their growth. In general terms it appears that lending to SMEs is seen as a high risk- business since most of these enterprises lack collateral. The problem does not appear to be lack of funds but rather how to make them accessible to SMEs. Available funds are often diverted to larger enterprises and only an insignificant number of SMEs seem able to attract bank financing. This perception therefore needs to change if financial institutions really want to do business with SMEs on a mutual basis and for the benefit of the two as most SMEs are reluctant to obtain loans from banks because of collateral security, high interest rate, untimely delivery of credits and other things. Though there is need to provide collateral security prior to lending as such to minimize the level of risk exposure there is need to evaluate credit rate on SMEs individualized cases so as to ensure there is optimal gain to both the lender and borrower. Moreover, financial institutions.

\section{RECOMMENDATIONS}

Many women entrepreneurs have no conventional collateral securities partly attributable to cultural beliefs among many ethnic communities in Kenya which prohibits women from owning ancestral property such as land. FIs should accept business assets and introduce group guarantee, where borrowers form social groupings for the purpose of co-guaranteeing one another. This will reduce level of risk from FIs to the borrowers hence encouraging FIs to grant loans to borrowers consequently increasing credit access. As part of affirmative action, the government should come up with a soft alternative to title deeds which will enable potential women entrepreneurs compete with men in borrowing or accessing credit finance to ensure sustainability in entrepreneurial activities like fellow businessmen. Such examples include but not limited to guarantee funds. In relation to the numerous women owned SMEs which outnumber few lending institutions, the government of Kenya needs to come up with fiscal policy which allows proliferations of credit providers in remote villages to ensure accessibility. As most of the SMEs, especially in their early stage, have a weak capitalization, they are not able to provide the required collateral to secure their repayment. It is recommended that institutions reduce the collateral requirements to encourage SMEs to apply for loans. 


\section{References}

Advani, M.L., (2007). SMEs' Access to Debt Finance: A Comparison of Male-Owned and Female-Owned Businesses in Ghana. International Journal of Entrepreneurship and Innovation, 7(2), 105-112.

Agarwal, B. (2011). Gender and the Land Rights: Exploring the New Prospects in the State, Market and Family. Agrarian Change Journal, 1(2), 184-224.

Alila, K. (2012). Micro and Small Enterprises in Kenya on Achievement of Kenya's Vision 2030. Finance and Accounting Research Journal, 1(2),18-20.

Atieno, R. (2001). Formal and informal institutions' lending policies and credit access by small-scale enterprises in Kenya: an empirical assessment. AERC Research paper 111 Nairobi.

Baloi, D., \& Price, A. D. (2011). Modelling global risk factors affecting construction cost performance. International Journal of Project Management, 21(1), 261-269.

Becke, T and Hesse, H. (2008), Why are interest spreads so high in Uganda? Journal of Development Economics, 88(9), 192-204.

Fletschner, W. (2009). Asymmetric information in credit market. Journal of Banking and Finance, 22 (6), 613-677.

Ingram D., (2011). Economic analysis of loan repayment capacity of small-holder cooperative farmers in Yewa North Local Government Area of Ogun State, Nigeria. African Journal of Agricultural Research, 7(13), 345-407.

Kariuki, C. N. N. (2015). Factors affecting development of strategic plans in SMEs: A case study of clothing shops in Nairobi, Kenya (Doctoral dissertation, United 88 States International University-Africa). Retrieved from http://erepo.usiu.ac.ke/handle/123456789/62

Ledgerwood, J. (2008). Microfinance Handbook: Institutional and Financial Perspective. Washington DC: World Bank.

Lore, J.N. (2011). Optimal credit limits management under different information regimes, Journal of Banking and Finance, 6(2): 463-487.

Makena, R.,H., Said, S. B., Jayaraman, K., \& Ismail, I. (2014). Factors influencing the Small and the Medium Enterprises (SMEs) in obtaining Loan. The International Journal of Economic Policy Studies, 7(13),31 - 38.

Mbogo, E., (2013). The collaterals provided by small scale farmers to access loans. Greener Journal of Agricultural Sciences, 3 (2), 120-127.

Namusonge, M. (2006). The role of entrepreneurship, education and training in stimulating entrepreneurial careers. A paper presented during the $3^{\text {rd }}$ International Entrepreneurship Conference organized by United States International University (USIU), Nairobi, Kenya.

Ondiege, B.M. (2011) Moving out of Poverty in Tanzania: Evidence from Kagera. Journal of Development Studies, 5(9), 432-454.

Robb, A. (2012). Entrepreneurial Performance by Minorities and Women. Journal on Development of Entrepreneurship, 1(4), 383-399.

Ukpore, W.E. (2009). Sources of SME credit in developing countries. The International Journal in Business and Social Science, 4(1), 106-115. 